\title{
Co istotnego zapamiętamy z nowości kończącego się roku w nadciśnieniu płucnym?
}

What is important to remember from the novelty of the ending year in pulmonary hypertension?

\section{Ewa Lewicka}

Klinika Kardiologii i Elektroterapii Serca Gdańskiego Uniwersytetu Medycznego

\section{STRESZCZENIE}

Nadciśnienie płucne (PH) jest zespołem chorobowym o złożonej i wieloczynnikowej etiologii. Obecnie dyskutowane jest wprowadzenie nowej definicji PH i rozpoznawania go w przypadku stwierdzenia w cewnikowaniu serca średniego ciśnienia w tętnicy płucnej powyżej $20 \mathrm{~mm} \mathrm{Hg}$ (dotąd > $25 \mathrm{~mm} \mathrm{Hg}$ ).

W ostatnich latach stosowanie tak zwanej terapii celowanej - ukierunkowanej na patomechanizmy tętniczego nadciśnienia płucnego (PAH) przyczyniło się do poprawy przeżywalności w tej grupie chorych. Dalszy postęp dokonał się dzięki rozwojowi nowych strategii terapii łączonej oraz eskalacji leczenia - w celu uzyskania u chorego profilu niskiego ryzyka zgonu. Współczesne postępowanie w PAH, obok jak najszybszego rozpoznania choroby i wdrożenia specjalistycznego leczenia, obejmuje przeprowadzanie regularnych kontroli z kompleksową oceną stanu klinicznego chorych, tolerancji wysiłku i funkcji prawej komory.

Choroby Serca i Naczyń 2019, 16 (1), 24-27

Słowa kluczowe: nadciśnienie płucne, tętnicze nadciśnienia płucne

\section{ABSTRACT}

Pulmonary hypertension (PH) is a complex disease with multifactorial etiology. Currently, a new definition and $\mathrm{PH}$ recognition is discussed if mean pulmonary artery pressure during right heart catheterisation is above $20 \mathrm{~mm} \mathrm{Hg}$ (previously > $25 \mathrm{~mm} \mathrm{Hg}$ ).

In recent years, the use of so-called targeted therapy - focused on pathomechanisms of pulmonary arterial hypertension (PAH) contributed to improved survival in this group of patients. Further progress was made due to the development of new combined therapy strategies and escalation of treatment - in order to obtain patients' low risk profile. Contemporary proceedings in $\mathrm{PAH}$, in addition to the prompt diagnosis of the disease and the implementation of specialized treatment, include regular controls with a comprehensive assessment of exercise tolerance, right ventricular function and the clinical status of patients.

\section{Choroby Serca i Naczyń 2019, 16 (1), 24-27}

Key words: pulmonary hypertension, pulmonary arterial hypertension

Nadciśnienie płucne (PH, pulmonary hypertension) to grupa chorób krążenia płucnego, których wspólną cechą jest zwiększenie średniego ciśnienia w tętnicy płucnej. Tym samym, choć można podejrzewać PH na przykład na 
podstawie badania echokardiograficznego dla ustalenia takiego rozpoznania, niezbędne jest wykonanie cewnikowania serca, w którym w spoczynku stwierdza się wartość średniego ciśnienia w tętnicy płucnej nie mniejszą niż $25 \mathrm{~mm} \mathrm{Hg}$.

W aktualnej klasyfikacji PH wyróżnia się:

- tętnicze nadciśnienia płucne;

- chorobę zarostową żył płucnych i/lub kapilarną hemangiomatozę płucną;

- przetrwałe nadciśnienie plucne noworodków ;

- nadciśnienie płucne spowodowane chorobą lewej części serca;

- nadciśnienie płucne w przebiegu chorób płuc i/lub hipoksji;

- przewlekłe zakrzepowo-zatorowe nadciśnienie płucne i inne zwężenia tętnic płucnych;

- nadciśnienie płucne o niewyjaśnionym lub wieloczynnikowym mechanizmie.

Według danych brytyjskich nadciśnienie płucne występuje u około 97 osób/mln [1]. W populacji polskiej echokardiograficzne cechy PH stwierdza się u 0,6\% osób dorosłych [2]. Najczęstszą przyczyną PH są choroby lewego serca, w tym niewydolność lewej komory [3]. Tętnicze nadciśnienia płucne (PAH, pulmonary arterial hypertension) jest chorobą rzadką — występuje u około 6,2\% pacjentów z PH. Roczna zapadalność na PAH w Europie wynosi 2-7,6/mln/rok, a chorobowość 15-26/mln [4-6].

Niezależnie od etiologii PH zmiany chorobowe dotyczą małych naczyń tętniczych krążenia płucnego. Wskutek pogrubienia błony środkowej i wewnętrznej tętniczek płucnych oraz skurczu mięśni gładkich tych naczyń dochodzi do wzrostu oporu naczyniowego. Prowadzi to do wzrostu ciśnienia w pniu płucnym i jego odgałęzieniach $\mathrm{w}$ celu zapewnienia stałego przepływu w łożysku płucnym. Ten wzrost ciśnienia powoduje zwiększenie obciążenia następczego prawej komory serca, co prowadzi do jej przerostu i powiększenia, a ostatecznie do rozwoju prawokomorowej niewydolności serca.

Tętnicze nadciśnienia płucne jest chorobą o szczególnie niepomyślnym rokowaniu [3]. Przed wprowadzeniem do leczenia tak zwanej terapii celowanej czas przeżycia chorych wynosił (mediana) 2,8 roku od rozpoznania PAH [7]. Początkowe objawy są niecharakterystyczne i najczęściej należą do nich duszność, osłabienie, męczliwość, rzadziej bóle dławicowe lub omdlenia, przy tym objawy te są często spotykane w chorobach płuc lub lewego serca. Z powodu tego niespecyficznego obrazu klinicznego od pierwszych objawów do ustalenia rozpoznania często mija kilkanaście miesięcy [8], a u większości pacjentów choroba jest wówczas w zaawansowanym stadium III-IV klasie niewydolności według Światowej Organizacji Zdrowa (WHO, World Health Organization) New York Heart Association (NYHA). U 3,9-5\% pacjentów choroba może być uwarunkowana genetycznie, dlatego badania nad aspektami genetycznymi PAH mają istotne znaczenie dla jego wcześniejszego rozpoznawania u członków rodzin pacjentów z PAH [9].

Najczęstszą przyczyną zgonu u chorych z PAH jest progresja niewydolności serca (49\%), niewydolność oddechowa (18\%) lub nagły zgon sercowy (17\%) [10]. Wczesne rozpoznanie ma zasadnicze znaczenie dla rokowania, ponieważ zastosowanie nowoczesnego specjalistycznego leczenia znacznie wydłuża przeżycie chorych. Podstawę leczenia stanowi znajomość patogenezy $\mathrm{PAH}$, ponieważ wiadomo, że przyczynami nadmiernej proliferacji śródbłonka tętniczek płucnych, skurczu i przerostu ich błony mięśniowej oraz zmian zakrzepowych w łożysku płucnym są uszkodzenie i dysfunkcja wydzielnicza śródbłonka. Z jednej strony prowadzi to do niedoboru tlenku azotu i prostacykliny, a z drugiej do nadmiaru endoteliny $\mathrm{i}$ tromboksanu. Obecnie w ramach tak zwaneh terapii celowanej PAH stosuje się leki zwiększające dostępność tlenku azotu w łożysku naczyniowym płuc (np. inhibitory fosfodiesterazy 5), analogi prostacykliny (prostanoidy) i leki blokujące receptory dla endoteliny 1 .

W marcu 2018 roku w Nicei po raz szósty odbyła się bardzo ważna konferencja World Symposium on Pulmonary Hypertesion (6WSPH), w czasie której między innymi zaproponowano nową definicję hemodynamiczną rozpoznawania PH. Ponieważ fizjologicznie średnie ciśnienie w tętnicy płucnej nie powinno w spoczynku przekraczać $20 \mathrm{~mm} \mathrm{Hg}$, to w nowej definicji obniżono wartość graniczną PH z 25 do $20 \mathrm{~mm} \mathrm{Hg}$, przy jednocześnie podwyższonym średnim oporze naczyniowym (PVR, pulmonary vascular resistance) ponad $3 \mathrm{j}$. Wooda i ciśnieniu zaklinowania (PCWP, pulmonary capillary wedge pressure) poniżej $15 \mathrm{~mm} \mathrm{Hg}$. Trudno przewidzieć, czy definicja ta znajdzie się za kilka lat w nowych wytycznych dotyczących PH, ale niewątpliwie przyczyniłoby się to do wcześniejszego leczenia chorych z PAH.

W literaturze dotyczącej PAH wiele miejsca poświęca się zagadnieniu lepszego wykorzystania dostępnych obecnie metod i strategii terapeutycznych. Obok wczesnego rozpoznania choroby i wdrożenia specjalistycznego leczenia istotne znaczenie ma stratyfikacja ryzyka u poszczególnych chorych z PAH. W wytycznych Europejskiego 
Towarzystwa Kardiologicznego (ESC, European Society of Cardiology) z 2015 roku na temat diagnostyki i leczenia PH [1] zaproponowano nowy model oceny ryzyka uwzględniający różne parametry, tj. kliniczne, echokardiograficzne, spiroergometryczne, wyniki badań laboratoryjnych oraz cewnikowania serca. Na tej podstawie zaproponowano także, jakie powinny być cele leczenia PAH. Przyjęte kryteria oceny ryzyka stanowily opinię ekspertów $\mathrm{w}$ tej dziedzinie, natomiast przydatność takiej oceny zwalidowano w opublikowanych niedawno wynikach trzech dużych rejestrów obejmujących pacjentów z PAH [11-13]. We wszystkich rejestrach wskazywano, że im niższe ryzyko oceniane na podstawie kalkulatora ryzyka zaproponowanego w wytycznych ESC z 2015 roku, tym lepsza przeżywalność chorych. W czasie wspomnianego już kongresu 6WSPH zaproponowano uproszczoną kalkulację ryzyka u chorych z PAH na podstawie oceny kilku parametrów, takich jak klasa czynnościowa według WHO, dystans pokonany przez chorego $\mathrm{w}$ teście 6-minutowego marszu, stężenia peptydów natriuretycznych (peptydu natriuretycznego typu B [BNP, B-type natriuretic peptide] lub N-koncowego fragmentu propeptydu natriuretycznego typu $B$ [NT-proBNP, N-terminal pro-B-type natriuretic peptide) oraz wynik cewnikowania serca (średnie ciśnienie w prawym przedsionku, rzut serca i saturacja mieszanej krwi żylnej).

Obecnie w leczeniu PAH zaleca się tak zwaną strategię ukierunkowaną na cel, jakim jest uzyskanie u chorego profilu niskiego ryzyka zgonu według wytycznych ESC z 2015 roku. Wiadomo przy tym, że zastosowanie terapii łączonej, na przykład dwoma lekami oddziałującymi na różne szlaki patogenetyczne $\mathrm{PAH}$, przynosi bardzo istotne i wymierne korzyści kliniczne, takie jak zmniejszenie częstości hospitalizacji, pogorszenia klinicznego oraz zmniejszenie ocenianych łącznie częstości hospitalizacji i zgonów. Dlatego obecnie podkreśla się znaczenie tak zwanego leczenia z wyprzedzeniem (upfront combination therapy), czyli rozpoczynania leczenia PAH od początku dwoma lub trzema lekami, zwłaszcza u chorych z grupy wysokiego ryzyka. Na efektywność takiego postępowania wskazują wyniki badania AMBITION [14], w którym wykazano, że u chorych leczonych od początku tadalafilem i ambrisentanem uzyskano obniżenie ryzyka pogorszenia klinicznego o 50\%. Po roku u $89 \%$ pacjentów w grupie poddanej terapii łączonej nie stwierdzano pogorszenia klinicznego w porównaniu z 75,5\% w grupie poddanej monoterapii, a po 2 latach, odpowiednio, u $79,7 \%$ w porównaniu z $63,2 \%$ chorych.
Ważnym faktem w Polsce jest wprowadzenie, począwszy od 1 listopada 2018 roku, nowego programu leczenia PAH oraz zakrzepowo-zatorowego nadciśnienia płucnego refundowanego przez Narodowego Funduszu Zdrowia (NFZ). Ważnymi elementami tego nowego programu są ocena skuteczności leczenia na podstawie wytycznych ESC, terapia dwulekowa z zastosowaniem bosentanu (inhibitor receptorów endotelinowych), możliwość terapii trójlekowej, leczenie z zastosowaniem prostacyklin u dzieci oraz wprowadzenie nowej cząsteczki, jaką jest riocyguat (bezpośredni stymulator cyklazy guanylowej). Program terapeutyczny NFZ jest realizowany od 2008 roku, natomiast dzięki wprowadzonym zmianom możliwe będzie bardziej efektywne leczenie chorych, zgodnie ze standardami europejskimi.

\section{PIŚMIENNICTWO}

1. Galiè N, Humbert M, Vachiery JL, et al. ESC Scientific Document Group . 2015 ESC/ERS Guidelines for the diagnosis and treatment of pulmonary hypertension: The Joint Task Force for the Diagnosis and Treatment of Pulmonary Hypertension of the European Society of Cardiology (ESC) and the European Respiratory Society (ERS): Endorsed by: Association for European Paediatric and Congenital Cardiology (AEPC), International Society for Heart and Lung Transplantation (ISHLT). Eur Respir J. 2015; 46(4): 903-975, doi: 10.1183/13993003.01032-2015, indexed in Pubmed: 26318161.

2. Kopeć G, Sobień B, Podolec M, et al. The prevalence of abnormal echocardiographic findings in a sample of urban adult population. Kardiol Pol. 2014; 72(1): 42-49, doi: 10.5603/KP.a2013.0178, indexed in Pubmed: 23990226.

3. Strange G, Playford D, Stewart S, et al. Pulmonary hypertension: prevalence and mortality in the Armadale echocardiography cohort. Heart. 2012; 98(24): 1805-1811, doi: 10.1136/heartjnl-2012-301992, indexed in Pubmed: 22760869.

4. Humbert M, Sitbon O, Chaouat A, et al. Pulmonary arterial hypertension in France: results from a national registry. Am J Respir Crit Care Med. 2006; 173(9): 1023-1030, doi: 10.1164/rccm.200510-1668OC, indexed in Pubmed: 16456139.

5. Peacock AJ, Murphy NF, McMurray JJV, et al. An epidemiological study of pulmonary arterial hypertension. Eur Respir J. 2007; 30(1): 104-109, doi: 10.1183/09031936.00092306, indexed in Pubmed: 17360728.

6. McGoon MD, Benza RL, Escribano-Subias P, et al. Pulmonary arterial hypertension: epidemiology and registries. J Am Coll Cardiol. 2013; 62(25 Suppl): D51-9

7. D'Alonzo GE, Barst RJ, Ayres SM, et al. Survival in patients with primary pulmonary hypertension. Results from a national prospective registry. Ann Intern Med. 1991; 115(5): 343-349, indexed in Pubmed: 1863023.

8. Benza RL, Miller DP, Barst RJ, et al. An evaluation of long-term survival from time of diagnosis in pulmonary arterial hypertension from the REVEAL Registry. Chest. 2012; 142(2): 448-456, doi: 10.1378/chest.11-1460, indexed in Pubmed: 22281797.

9. Lewicka E, Dąbrowska-Kugacka A, Chmara M, et al. Genetics and genetic testing in pulmonary arterial hypertension. J Rare Cardiovasc Dis. 2018; 3(7): 226-9.

10. Hoeper MM, Galié N, Murali S, et al. Outcome after cardiopulmonary resuscitation in patients with pulmonary arterial hypertension. Am J Respir Crit Care Med. 2002; 165(3): 341-344, doi: 10.1164/ajrccm.165.3.200109-0130c, indexed in Pubmed: 11818318. 
11. Hoeper MM, Kramer T, Pan Z, et al. Mortality in pulmonary arterial hypertension: prediction by the 2015 European pulmonary hypertension guidelines risk stratification model. Eur Respir J. 2017; 50(2) doi: 10.1183/13993003.00740-2017, indexed in Pubmed: 28775047.

12. Boucly A, Weatherald J, Savale L, et al. Risk assessment, prognosis and guideline implementation in pulmonary arterial hypertension. Eur Respir J. 2017; 50(2), doi: 10.1183/13993003.00889-2017, indexed in Pubmed: 28775050
13. Kylhammar D, Kjellström B, Hjalmarsson C, et al. A comprehensive risk stratification at early follow-up determines prognosis in pulmonary arterial hypertension. Eur Heart J. 2018; 39(47): 4175-4181, doi: 10.1093/eurheartj/ehx257, indexed in Pubmed: 28575277.

14. Coghlan JG, Galiè N, Barberà JA, et al. AMBITION investigators, AMBITION Investigators. Initial use of ambrisentan plus tadalafil in pulmonary arterial hypertension. N Engl J Med. 2015; 373(9): 834-844, doi: 10.1056/NEJMoa1413687, indexed in Pubmed: 26308684 